Delgado, J.R. (1959) Electronic command of movement and behavior. Transactions of the New York Academy of Sciences, 21, 689-699.

Estabrooks, G.H. (1971) Hypnosis comes of age. Science Digest, April, 44-50.

FARETRA, G. \& Bender, L. (1964) Autonomic nervous system responses in hospitalised children treated with LSD and UML. Recent Advances in Biological Psychiatry, 7, 1-8.

Gillmor, D. (1987) I Swear By Apollo. Dr. Ewen Cameron and the CIA-Brainwashing Experiments. Montreal: Eden Press.

MerskeY, H. (1995) Multiple personality disorder and false memory syndrome. British Journal of Psychiatry, 166, 281-283.

Ross, C.A. (1995) The validity and reliability of dissociative identity disorder. In Dissociative Identity Disorder. Theoretical and Treatment Controversies (eds L. Cohen, J. Berzoff \& M. Elin), pp. 65-84. Northvale, New Jersey: Jason Aronson.

-, Norton, G.R. \& Fraser, G.A. (1989) Evidence against the iatrogenesis of multiple personality disorder. Dissociation, 2 , $61-65$.

1701 Gateway, Suite 349

Richardson, Texas 75080

SIR: Merskey's arguments (BJP, March 1995, 166, 281-283) include obvious fallacies and not so obvious fallacies. Let me cite one of each.

Merskey opens with the argument that multiple personality disorder is invalid because many people believe in it (there are over 3000 members in the International Society for the Study of Dissociation, and most members have personally treated at least one case) and because many people do not believe in it (all those who have never treated a case). But something is not proved valid or invalid because many people believe it or disbelieve it. He sets the tone of his editorial by opening with an emotional, not a scientific argument.

Moreover, things once thought rare have frequently been found to be relatively common, e.g. child abuse and manic depression. I recall a quarter century ago when the latter was vastly underdiagnosed here in the USA and we learned a lesson from our British colleagues. If we can learn from the British about affective disorders, can the British learn from us about dissociative disorders?

An example of a not so obvious fallacy, or really a half truth, is Merskey's statement that "memory itself is thought to involve active reconstruction". However, reconstructive memory is not the only kind of memory. There is also photographic memory, which happens to be more evident in childhood, tending to wane somewhat with age. (Talking about age-related cognitive strategies, one should also mention imaginary playmates in childhood.) Why do members of the False Memory Syndrome Foundation like Merskey always forget about photographic memory when discussing the basic nature of memory?
I agree that there have been instances of overdiagnosis of multiple personality. I agree that there are misguided therapists around who find memories of abuse that never happened. But if you think that accounts for most of what is going on over here in the dissociative disorders field, you are getting your information from people with relatively little actual experience or training in this area.

\section{K.A. NAKDIMEN}

One Lincoln Plaza (12M)

New York, NY 10023

SIR: Merskey (BJP, March 1995, 166, 281-283) highlighted the classification of muiltiple personality disorder (MPD) as a dissociative disorder and showed how MPD and false memory syndrome have been linked to childhood sexual abuse. The importance of cultural and social factors in dissociative disorders is well known and the article also served to underline the contribution of these factors in what society accepts as justified manifestations of psychic distress.

However, there is a danger in condemning too widely therapists working with the victims of sexual abuse. In particular the "typical" picture of a therapist "immediately searching for repressed memories of childhood abuse" in which "the patient is quickly encouraged to produce evidence" or else "more pressure is exerted" is unrecognisable in any mainstream work on the topic (Walker, 1990). Likewise therapists for MPD being regarded as "leading participants" in treatment methods for sexual abuse would not seem to be the case in the UK (Hobbs, 1990). Therapy for survivors of sexual abuse is consistently aware of the power of the therapist and its potential for further detriment.

Recent work has confirmed childhood sexual abuse as an aetiological factor in mental illness (Mullen, 1993). Drawing attention to the cases in which dissociative mechanisms or poor therapeutic practice produce spurious claims of sexual abuse is useful but should not obscure the much commoner problems that the effects of childhood sexual abuse can cause.

Hobbs, M. in Horton, K. \& Cowan, P. (1990) Dilemmas and Difficulties in the Management of Psychiatric Patients. Oxford University Press.

Mullen, P.E. (1993) Childhood, Sexual Abuse and Mental Health in Adult Life. British Journal of Psychiatry, 163, 731-732.

WALKER, M. (1990) Women in Therapy and Counselling. Open University Press.

Rathbone Hospital

C. HALEY 